\title{
PRIHVAĆENOST PODUZETNIČKOG NAČINA RAZMIŠLJANJA KOD STUDENATA ${ }^{3}$
}

\begin{abstract}
SAŽETAK
Poduzetnički način razmišljanja drži se jednim od najvažnijih koncepata koji promovira i potiče Europska unija u funkciji potpunijeg iskorištavanja i razvoja osobnih i društvenih potencijala, jačanja konkurentske snage gospodarstva i uloge pratećih institucija, posebno obrazovnih. Surha ovog istraživanja bila je uturditi čimbenike koji jačaju sklonost poduzetničkom ponašanju i vjerojatnost pokretanja posla. lako nositelji politika imaju velika očekivanja od uloge visokoškolskog poduzetničkog obrazovanja u procesu širenja poduzetničkog načina razmišljanja, slijedom rezultata istraživanja u ovom radu poduzetničko obrazovanje u Republici Hrvatskoj ne predstavlja značajan čimbenik jačanja poduzetničkog ponašanja i stjecanja poduzetničkih kompetencija. Naime, rezultati istraživanja na uzorku studenata različitih studija Veleučilišta u Rijeci upućuju da se studenti mogu više oslanjati na osobno iskustvo i poduzetničko pdorijetlo u obitelji, kao čimbenike koji su pozitivno i statistički značajno povezani sa sklonosti poduzetničkom ponašanju te vjerojatnosti pokretanja vlastitog posla. Ujedno je utvrđeno da sklonost poduzetničkom ponašanju predstavlja statistički značajan prediktor vjerojatnosti pokretanja vlastitog posla. Slijedi da su nužne promjene u visokoškolskom poduzetničkom obrazovanju, kako u pogledu ishoda učenja, tako i metoda poučavanja, da bi ono još kvalitetnije ispunilo svoju misiju u jačanju poduzetničkog načina razmišljanja i poduzetničkog ponašanja.
\end{abstract}

Ključne riječi: poduzetničko ponašanje, poduzetničke kompetencije, poduzetničko obrazovanje

\section{UVOD}

Pronalaženje novih i unaprjeđenje postojećih strategija i pristupa za ostvarenje ekonomskog rasta i razvoja te bolje konkurentnosti na svim razinama sve više podrazumijeva isticanje poduzetništva kao jednog od najvažnijih elemenata ostvarenja tih ciljeva i to ne samo u profitnom, već sve više i u javnom sektoru. Potreba usvajanja poduzetničkih znanja i vještina istovremeno postaje nužnost ne samo za uspješnu realizaciju samostalnih poduzetničkih pothvata, već i za uspješno djelovanje zaposlenika različitih poslovnih subjekata (Širola, 2014:1). lako su brojni autori prihvatili i potvrdili Druckerovo viđenje (1985, citirano u Kuratko, 2004: 6) kojim obrazlaže da „poduzetništvo nije mit, nije misterija i nema ništa s genima, već je riječ o disciplini, koja se, kao i svaka druga disciplina, može poučavati", poduzetničko obrazovanje nije jedini čimbenik stvaranja poduzetničkih kompetencija i uspješnih poduzetnika, već je to poduzetničko ponašanje (Sedlan König, 2012a: 146). Stoga je problem koji se analizira u radu utvrđivanje pozicije visokoškolskog poduzetničkog obrazovanja u Republici Hrvatskoj u kontekstu važne uloge koja se daje poduzetničkom obrazovanju u

Dr. sc., viši predavač, Veleučilište u Rijeci, Vukovarska 58, 51000 Rijeka, Hrvatska. E-mail: davor.sirola@veleri.hr

Bacc. oec., studentica, Veleučilište u Rijeci, Vukovarska 58, 51000 Rijeka, Hrvatska.E-mail: Ibaltic@veleri.hr

Datum primitka rada: 15. 1. 2017.; datum prihvaćanja rada: 1.3. 2018. 
sklopu snažnog zagovaranja razvoja poduzetničkog načina razmišljanja od strane Europske unije i na nacionalnoj razini (primjerice: Akcijski plan za poduzetništvo, European Commission, 2013: 3 i Strategija razvoja poduzetništva 2013. - 2020., Ministarstvo poduzetništva i obrta, 2013: 13, dokumenti koji među najvažnijim ciljevima ističu poduzetničko obrazovanje). Cilj tog obrazovanja treba biti stjecanje poduzetničkih kompetencija

Svrha rada je analiza utjecaja koji na poduzetnički način razmišljanja i stjecanje poduzetničkih kompetencija imaju različiti čimbenici koji mogu pridonijeti prepoznavanju i osnaživanju poduzetničkog ponašanja kod studenata, pri čemu je glavni cilj utvrditi kakav utjecaj na poduzetničko ponašanje ima formalno poduzetničko obrazovanje. Rad je strukturiran tako da nakon uvoda slijedi pregled literature, zatim prikaz metodologije koji uključuje hipoteze rada, rezultati istraživanja te rasprava i zaključak.

\section{PREGLED LITERATURE}

Brojni stručnjaci i znanstvenici suglasni su da poduzetnici razmišljaju drukčije od nepoduzetnika, primjerice, tradicionalnih menadžera (Hisrich et al., 2011: 29 i 33) te da pri donošenju različitih odluka u neizvjesnom okruženju koriste pristup koji se prepoznaje kao poduzetnički način razmišljanja (engl. entrepreneurial mindset). Pritom se dio znanstvenika i predlagača obrazovnih politika i dalje pita "može li se poduzetništvo (i poduzetnič̌ki način razmišljanja) poučavati." lako mnogi drže da postoji dovoljno dokaza da se poduzetništvo može poučavati (primjerice: Drucker, 1985; Gorman et al. 1997, citirano u Kuratko, 2003: 12), neki smatraju da se u učionici ne mogu poučavati određeni aspekti poduzetništva, poput samopouzdanja, ustrajnosti te visoke razine energije kod poduzetnika (Miller, 1987, citirano u Sedlan König, 2012a: 26), dok, primjerice, Martin et al. (2013: 8-9) ističu da je pravo pitanje kako mjeriti učinke poduzetničkog obrazovanja u pogledu razvoja vještina koje potiču poduzetnički način razmišljanja, kao važan čimbenik izgradnje poduzetničkog ponašanja.

Značaj koncepta poduzetničkog načina razmišljanja prepoznat je i u definiciji poduzetništva koju je usvojila Europska komisija u tzv. Zelenoj knjizi - Poduzetništvo u Europi (European Commission, 2003: 6): „poduzetništvo je način razmišljanja, odnosno proces stvaranja i razvijanja ekonomskih aktivnosti kombiniranjem rizika, kreativnosti i/ili inovativnosti uz pouzdanu upravljačku strukturu unutar nove ili postojeće organizacije." Sedlan König (2012a: 146) poduzetništvo definira kombiniranjem definicija autora Bygrave i Hofer, 1991, Herron i Robinson,1993, Gibb i Cotton, 1998, kao: „skup ponašanja kojima se stvaraju i otkrivaju prilike, unose promjene i stvara organizacija kojoj je cilj ostvarivanje dodatne vrijednosti iskorištavanjem tih prilika i nošenje s većom razinom neizvjesnosti i složenosti poduzetnika." Iz ovako postavljene definicije proizlazi da poduzetničko ponašanje čine akcije i reakcije pojedinca koje predstavljaju odgovor na vanjske i unutrašnje poticaje, a potrebne su za kreiranje i otkrivanje prilika, unošenje promjena i stvaranje organizacija kojima je cilj iskorištavanje tih prilika i nošenje s većom razinom neizvjesnosti i složenosti.

Pritom je važno istaknuti da poduzetničko ponašanje nije samo rezultat karakteristika osobnosti (pojedinci in ili imaju ili nemaju, pa ih trebaju razvijati), niti samo okruženja ili karakteristika situacije (trebaju razvijati vještine i strategije za otkrivanje, identificiranje $\mathrm{i}$ iskorištavanje prilika 
koje imaju potencijal), nego je rezultat i poduzetničkih kompetencija koje se dijelom sastoje od tacitnog (iskustvenog, osjećajnog) znanja, ali i znanja koje se može poučavati i učiti (Sarasvathy, 2008, citirano Sedlan König, 2012a: 146). Sedlan König (2012a) je u svojoj disertaciji prepoznala šest elemenata koji djeluju na složeni fenomen poduzetničkog ponašanja: osobnost (demografski čimbenici i osobne značajke), stavovi i uvjerenja, namjere, okruženje, kompetencije i obrazovanje (shema 1).

Shema 1. Konceptualni model poduzetničkog ponašanja

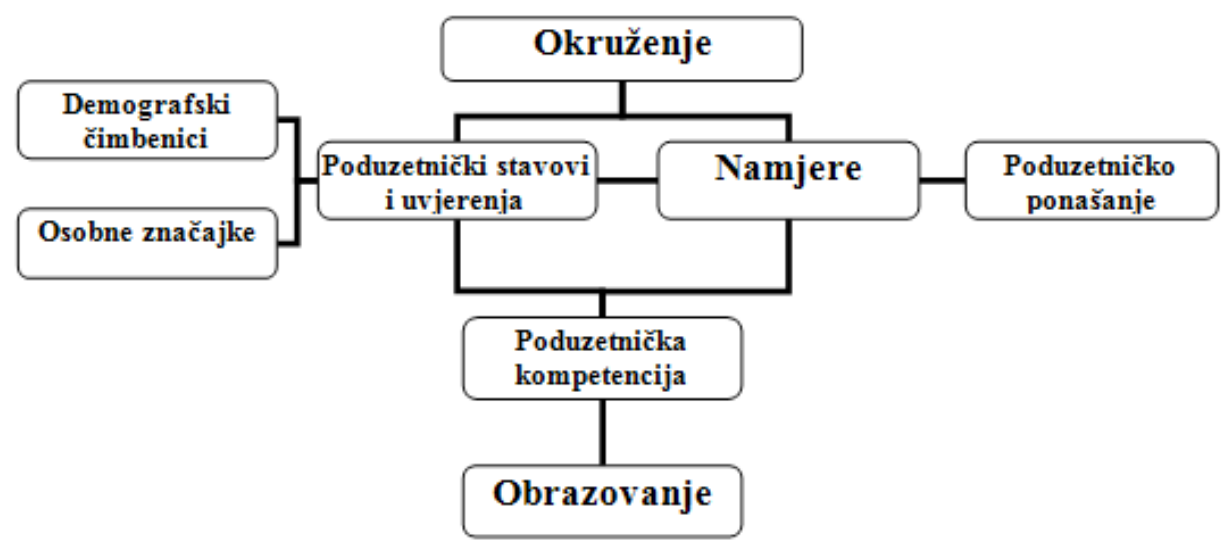

Izvor: Sedlan König, 2012a: 147

Umodelu prikazanom na shemi 1 treba posebno istaknuti (poduzetničke) namjerekoje su prepoznate kao najbolji pretskazatelj poduzetničkog ponašanja (primjerice, prema: Bird, 1988, Kolvereid, 1996, KruegeriBrazeal, 1994, Krueger etal.,2000, citirano u McGeeet al.,2009:965). Namjere su sveobuhvatno istraživane u području socijalne psihologije, gdje je ključni doprinos dala široko primijenjivana teorija planiranog ponašanja (Ajzen, 1991: 181-184), te u području poduzetništva iz kojeg je proizašla teorija poduzetničkog događaja (Shapero, 1982, citirano u Krueger et al., 2000: 418). Namjere Bird (1988: 442) definira kao stanje svijesti koje usmjerava pažnju osobe prema određenom cilju ili putu prema određenom postignuću. Poduzetničke namjere se definiraju različito, primjerice, kao usmjeravanje aktivnosti osobe prema formiranju novih poslovnih subjekata ili novih vrijednosti unutar postojećih poslovnih subjekata (Bird, 1988: 443), kao namjera da osoba postane samozaposlena (Crant, 1996, Kolvereid, 1996, citirano u lakovleva i Kolvereid, 2009: 69) ili kao namjera (vjerojatnost) pokretanja poslovnog pothvata, što se istražuje i u sklopu ovog rada (Reitan, 1998; Scherer et al., 1989; Bird, 1992; Krueger et al., 2000, citirano u lakovleva i Kolvereid, 2009: 69). Općenito vrijedi pravilo - što je jača namjera za određenim postupanjem, to je vjerojatnije njezino ostvarenje (Hisrich et al., 2011:57).

Namjera (sklonost) osobe da se uključi u poduzetničko ponašanje drži se odlučujućom za nastanak poduzetničkih aktivnosti (Bird, 1988:443; Krueger et al., 2000:414). Naime, rezultati brojnih istraživanja pokazali su da namjere bolje pretskazuju planirano ponašanje, poput poduzetništva, od primjerice, stavova, uvjerenja, osobnih značajki ili samih demografskih karakteristika osoba, koje predstavljaju udaljene elemente koji na poduzetničko ponašanje djeluju posredno, kao pretpostavke namjera (Kautonen et al., 2011:698). Tako demografski čimbenici, kao što su obitelj, dob, obrazovanje roditelja, 
spol, bračni status, obrazovanje i prethodno radno iskustvo te osobne značajke (primjerice: potreba za postignućem, motiviranost, inicijativa, kreativnost, interni locus kontrole, preuzimanje ukalkuliranog rizika, potrebaza samostalnošću isamopouzdanje) nemaju izravan utjecaj na poduzetničko ponašanje već na ponašanje utječu neizravno, kroz utjecaj na stavove i uvjerenja (Crant, 1996; Matthews i Moser, 1996; Mazzarol et al., 1999; Misra i Kumar, 2000, citirano u Sedlan König, 2012a: 147-148).

Obje prethodno spomenute teorije (modeli) koje se bave namjerama pokazale su visoku razinu kompatibilnosti i međusobne povezanosti te su istraživači dokazali da pretpostavke u oba modela podjednako dobro objašnjavaju varijance u namjerama, uz blagu prednost Shaperovom modelu (Krueger et al., 2000: 423-424). lakovleva i Kolvereid (2009: 70, 76 i 78), su uspješno integrirali modele i utvrdili da percipirana poželjnost i percipirana provedivost (Shaperov model) predstavljaju funkciju stavova, socijalnih normi i percipirane kontrole ponašanja (Ajzenov model), te su značajno i pozitivno povezani s poduzetničkim namjerama (novi model objašnjava $65 \%$ varijanci u namjerama pokretanja posla i samozapošljavanja).

Pretpostavke namjera u konceptualnom modelu na shemi 1 obuhvaćaju poduzetničke stavove i uvjerenja. Pod stavovima se podrazumijevaju stavovi prema poduzetništvu, sklonost poduzetničkom ponašanju (istražuje se i u sklopu ovog rada) te percepcija poželjnosti, dok uvjerenja podrazumijevaju razinu provedivosti ponašanja i procjena vlastitih sposobnosti (svijest o vlastitoj učinkovitosti) za poduzetničko ponašanje (Sedlan König, 2012a: 147 i 152). Pritom se svijest o (percipiranoj) vlastitoj poduzetničkoj učinkovitosti, odnosno vjerovanja ljudi o njihovim sposobnostima da stvore željenu razinu učinaka (koncept razvijen od Bandura, 1994: 2), pojavljuje kao element Ajzenovog i Shaperovog modela namjera. Nadalje, Boyd i Vozikis (1994, citirano u Sedlan König, 2012a: 154) utvrdili su da je vlastita učinkovitost ne samo prediktor poduzetničkih namjera (posredno i poduzetnička ponašanja), već i da određuje intenzitet poduzetničkih namjera, odnosno vjerojatnost da će one uzrokovati poduzetničko ponašanje.

Model prikazan na shemi 1 ukazuje i na važnost utjecaja čimbenika okruženja na poduzetničke namjere, poduzetničke stavove i uvjerenja. Pritom je kao važan čimbenik okruženja utvrđeno iskustvo u poduzetništvu, stečeno u okviru poduzetničke obitelji ili osobno (Sedlan König, 2012a: 158). Ovakav zaključak proizlazi i iz važnosti koja se iskustvu pridaje u različitim pristupima učenju te u društvenom ili demografskom pristupu istraživanja poduzetništva, gdje se analiziraju poduzetnikova iskustva iz djetinjstva i radno iskustvo (Sedlan König, 2012a: 18). Među pristupima učenju treba istaknuti da pojedinci u svakodnevnom životu nesvjesno prihvaćaju stajališta i pozitivne vrednote te vještine i znanja iz svakodnevnog iskustva, pa informalno obrazovanje ne treba zanemariti u razmatranju poduzetničkog obrazovanja. Slično tumače i konstruktivističke teorije prema kojima učenje uključuje stvaranje vlastitog znanja iz osobnog iskustva, a ne samo preslikavanje i oponašanje doživljenoga, dok teorija socijalnog konstruktivizma zastupa da održavanje motivacije za učenje znatno ovisi o vjeri pojedinca u vlastiti potencijal za učenje. Taj osjećaj sposobnosti i vjera u potencijal za rješavanje novih problema dolaze iz osobnog iskustva nošenja s problemima u prošlosti i puno su snažniji nego vanjsko priznaje i motivacija. (Sedlan König, 2012a: 28, 38 i 40). Slijedom prepoznate važnosti osobnog iskustva Boussouara i Deakins (1998, citirano u Sedlan König, 2012a: 26) su, ispitujući razvoj malih poduzeća visoke tehnologije, predložli da poduzetnici uče, ne kroz strukturiranu nastavu, već kroz iskustvo i metodu pokušaja i pogreške. 
Ključnu sastavnicu konceptualnog modela poduzetničkog ponašanja (shema 1) predstavlja poduzetničko obrazovanje. Pritom poduzetničko obrazovanje podrazumijeva sve aktivnosti kojima je cilj razvijanje poduzetničkog ponašanja i kompetencija, povećanje znanja pojedinaca o poduzetništvu te osposobljavanje za karijeru poduzetnika (Garavan i O'Cinneide, 1994, citirano u Sedlan König, 2012a: 2 ). Naime, s rastom promišljanja da je poduzetništvo ključan čimbenik ekonomskog rasta, znanstvenici su intenzivirali istraživanja poduzetničkog obrazovanja kao pretpostavke poduzetništva, iako teorijske podloge za to već postoje (Low i MacMillan, 1988; Davidsson et al., 2001; Haase i Lautensclager, 2011, citirano u Rideout i Gray, 2013: 331). Tako su ideje da se pojedinci motiviraju svojim uvjerenjem o vlastitim talentima i sposobnostima te posljedično uvjerenjem u uspješan ishod derivirane iz socijalno-kognitivne teorije koja se zasniva na važnosti učenja promatranjem, tj. ne samo kroz osobno ponašanje, već i kroz interaktivni odnos s okolinom, izravno, preko zastupnika i kolektivno (Bandura, 2001: 10 i 13). Slijedi da poduzetničko obrazovanje može razviti sposobnosti i kompetencije te omogućiti uvjerenost u vlastitu poduzetničku učinkovitost.

lako su provedena brojna istraživanja povezanosti poduzetničkog obrazovanja i poduzetništva, zaključci pregleda literature (od 1997. do 2011.) koji su pripremili Rideout i Gray (2013:336) potvrdili su zabrinutost prethodnih sličnih pregleda (Gorman et al., 1997; Vesper i Gartner, 1997; Honig, 2004; Fayolle, 2005; Lee i Wong, 2006, citirano u Rideout i Gray, 2013: 333). Naime, Rideout i Gray pronašli su samo 12 istraživanja koja zadovoljavaju (skromno) postavljene kriterije relevantnosti, a ti radovi pokazali su pretežito psihološke rezultate poduzetničkog obrazovanja (promjene u stavovima, namjerama, učenju), dok su samo tri rada (Kolvered i Moen, 1997; Charney et al., 2000; Paradi, 2002, citirano u Rideout i Gray, 2013: 345) dokazala učinke poduzetničkog obrazovanja kroz objektivne ishode koji su zanimljiviji donositeljima politika u ovom području (primjerice: pokretanje više start-up poduzeća u odnosu na studente bez poduzetničkog obrazovanja).

Istraživanja poveznica poduzetničkog obrazovanja i namjera su brojna, budući da je namjera pojedinca da se uključi u poduzetničko ponašanje ključna za poduzetničku aktivnost u društvu (Sedlan König, 2012a: 150). Tako je u pregledu literature istraživanja poduzetničkog obrazovanja kao pretpostavke poduzetničkih namjera koji su izradili Liñán i Fayolle (2015: 919), između ostalog, analizirana povezanost namjera s poduzetničkim obrazovanjem. Pritom većina rezultata empirijskih radova (analizirano 13 radova) upućuje da se visoka razina poduzetničkih namjera pripisuje poduzetničkom obrazovnom programu. Istovremeno rezultati evaluacije poduzetničkih obrazovnih programa (analizirano 30 radova), nisu konzistentni, budući da općenito potvrđuju njihov pozitivan utjecaj na poduzetničke namjere, no utvrđeni su i negativni učinci, kao i opadajući utjecaj koji se povezuje s povećanjem razine primljenih informacija ispitanika (redovito studenata), te je ukazano na moguće metodološke nedostatke kod dijela istraživanja. Slijedi da su potrebna rigoroznije koncipirana istraživanja, budući da dosadašnja skromno podupiru socijalno-kognitivnu teoriju prema kojoj poduzetničko obrazovanje utječe na vlastitu poduzetničku učinkovitost, slabo podržavaju povezanost s namjerama te daju ograničenu podršku široko istraživanoj Ajzenovoj teoriji o poveznici poduzetničkih namjera i poduzetničkih aktivnosti (ponašanja). Dodatnim istraživanjima trebalo bi dokazati ne samo funkcionira li poduzetničko obrazovanje, već $i$ kako treba funkcionirati da bi pozitivno utjecalo na poduzetničko ponašanje (Rideout i Gray, 2013: 345). 
Rastuća brzina promjena u suvremenom okruženju imperativno zahtijeva ubrzani razvoj odgovarajućih kompetencija. Poduzetničke kompetencije različito se definiraju (primjerice: Van Overveld i Van Goudoever, 1997; Bron, 1999; Hayton i McEvoy, 2006; Hoffmann, 1999, citirano u Mitchelmore i Rowley, 2010: 92), no uobičajeno definicije (poput uvodno istaknutih definicija u dokumentima Europske unije) uključuju: osnovne karakteristike, poput općih i specifičnih znanja, motive, osobine, vještine, sposobnosti, društvene uloge, uvjerenja i stavove potrebne za stvaranje i otkrivanje prilika u okruženju i unošenje promjena (prilagođeno prema Bird, 1995: 51 i Sedlan König, 2012a: 160). Budući da je cilj poduzetničkog obrazovanja razvoj poduzetničkih kompetencija (koje posredno utječu na poduzetničke stavove, uvjerenja i namjere), poduzetničke kompetencije prepoznate su kao krucijalni čimbenici u poticanju poduzetničkog načina razmišljanja i boljeg korištenja kreativnih potencijala, kako od strane znanstvenika (primjerice: Gibb, 2002; Henry et al., 2007; Lans et al., 2011, citirano u Sedlan König, 2013: 804), tako i od strane nositelja politika. Primjerice, u Europskoj uniji usvojen je Poduzetnički okvir kompetencija (Bacigalupo et al., 2016: 10 i 17), kojim su definirana tri područja s ukupno 15 poduzetničkih kompetencija te opći ishodi učenja na temelju kojih treba razviti specifične ishode pojedinog poduzetničkog obrazovanja.

Pored poduzetničkog okvira kompetencija Europske unije mnogi autori formirali su svoja viđenja ključnih poduzetničkih kompetencija. Primjerice, Mitchelmore i Rowley (2010: 100) predložili su okvir s četiri skupine (poduzetničke, poslovne i menadžerske, kompetencije međuljudskih odnosa te konceptualne i organizacijske kompetencije) i ukupno 41 vrstom kompetencija. Sedlan König (2012a: 161) je ukupno 29 kompetencija svrstala u tri kategorije (kognitivna, afektivna i bihevioralna) te zasebno prikazala tri popisa $s$ po devet poduzetničkih ponašanja, poduzetničkih atributa i poduzetničkih vještina (Gibb i Cotton, 1998, citirano u Sedlan König, 2012a: 248). U ovom radu slijedom istraživanja različitih obuhvata poduzetničkih kompetencija (Sedlan König, 2012b: 486), za samoprocjenu vlastitih poduzetničkih kompetencija studenata, odabrane su sljedeće kategorije poduzetničkih kompetencija: uočavanje tržǐnih prilika, uvjeravanje i pregovaranje, korištenje informacijske tehnologije, međuljudski odnosi, upravljanje financijama, prodaja i marketing, rad pod stresom, nošenje s izazovima, planiranje i nošenje s promjenama u okolini.

Brojne kompetencije koje su razni autori prepoznali kao važne za poduzetništvo ne nastaju isključivo u procesu poduzetničkog obrazovanja. Naime, učenje predstavlja društveni proces i događa se $u$ interakciji između pojedinaca kroz sudjelovanje $u$ aktivnostima svakodnevnog života, pa i sudjelovanjem u tzv. zajednicama prakse, prema Wengerovom modelu situacijskog učenja (Wenger, 1998, citirano u Sedlan König, 2012a: 191). Zajednice prakse predstavljaju zajedničke aktivnosti koje ispunjavanju tri uvjeta: članovi zajednice moraju imati zajedničko područje interesa, zajedničke aktivnosti i zajedničke standarde djelovanja. Najuspješnije su one zajednice koje kombiniraju entuzijazam i inicijativu članova s podrškom vodstva zajednice. Što se više članovi zajednice uključuju $\mathrm{u}$ aktivnosti zajednice to više razvijaju svoje kompetencije i pomiču se od perifernog sudjelovanja u radu do pune angažiranosti (Lave i Wenger, 1991, citirano u Sedlan König, 2012a: 192 i 194). U kontekstu visokoškolskog poduzetničkog obrazovanja važno je uzeti u obzir i utjecaj zajednica prakse u kojima studenti najčešće sudjeluju i gdje razvijaju sposobnost učenja iz odnosa s drugima, 'igraju' različite uloge, primijenjuju obrazovanjem stečene kompetencije te kroz iskustvo usvajaju nove. Stoga se i ovom radu kroz samoprocjenu istražuje ne samo uspješnost u stjecanju poduzetničkih 
kompetencija kroz formalno obrazovanje, već i kroz osobno iskustvo te sudjelovanje studenata u zajednicama prakse (neprofitne udruge i sportska natjecanja - klubovi).

\section{METODOLOGIJA ISTRAŽIVANJA}

Slijedom uvodno predstavljenog problema i svrhe istraživanja te pregleda literature postavljene su hipoteze istraživanja u sklopu ovog rada i razvijen konceptualni model veza među postavljenim hipotezama (shema 2 u nastavku):

H1: Samoprocjena vlastitih poduzetničkih kompetencija (stečenih kroz školu/fakultet, osobno iskustvo, natjecanja ili udruge) pozitivno je i značajno povezana sa sklonosti poduzetničkom ponašanju.

H2: Samoprocjena vlastitih poduzetničkih kompetencija (stečenih kroz školu/fakultet, osobno iskustvo, natjecanja ili udruge) pozitivno je i značajno povezana s vjerojatnošću pokretanja vlastitog posla.

H3: Sklonost poduzetničkom ponašanju izravno, pozitivno i značajno utječe na vjerojatnost pokretanja vlastitog posla.

Postavljene hipoteze prikazane su kroz model prikazan na shemi 2, gdje samoprocjena vlastitih poduzetničkih kompetencija predstavlja prediktorsku (nezavisnu) varijablu, vjerojatnost pokretanja posla (kriterijsku) zavisnu varijablu, a sklonost poduzetničkom ponašanju pojavljuje se kao zavisna varijabla u hipotezi $\mathrm{H} 1$ te kao prediktor $\mathrm{u}$ hipotezi $\mathrm{H} 3$.

Shema 2. Konceptualni model veza među postavljenim hipotezama

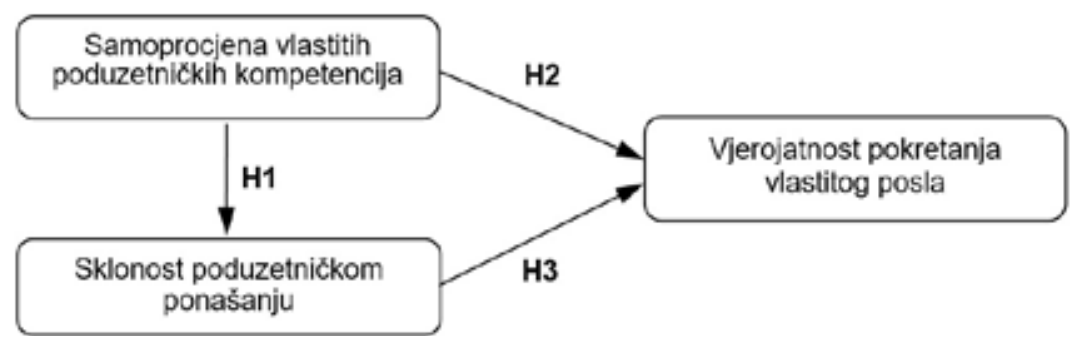

Izvor: autori (prilagođeno prema Sedlan König, 2012a: 147)

Instrument istraživanja u ovom radu predstavlja anketni upitnik koji je izrađen u alatu Google Docs, tako da je podijeljen u pet cjelina koje slijede hipoteze prikazane na modelu (shema 2): 1) demografski čimbenici (spol, godina i vrsta studija); 2) okruženje (članovi uže obitelji poduzetnici); 3) poduzetnički stavovi (sklonost poduzetničkom ponašanju); 4) poduzetničke namjere (vjerojatnost pokretanja vlastitog posla) te 5) samoprocjena vlastitih poduzetničkih kompetencija studenata (stečenih kroz školu/fakultet, osobno iskustvo, natjecanja ili u udrugama). 


\section{D. Širola, L. Baltić: Prihvaćenost poduzetničkog načina razmišljanja kod studenata Zbornik Veleučilišta u Rijeci, Vol. 6 (2018), No. 1, pp. 197-216}

Ispitanici su izvršili samoprocjenu sljedećih vlastitih poduzetničih kompetencija: uočavanje tržišnih prilika, uvjeravanje i pregovaranje, korištenje informacijske tehnologije, međuljudski odnosi, upravljanje financijama, prodaja i marketing, rad pod stresom, nošenje s izazovima, planiranje i nošenje s promjenama u okolini. Pritom cjeline 1) i 2) upitnika sadrže kontrolne varijable istraživanja. Upitnik je ukupno sadržavao 12 pitanja te 42 potpitanja. S izuzetkom kontrolnih varijabli, sve ostale varijable istraživane su pomoću ordinalnih ljestvica i to Likertove ljestvice s pet razina od $1=$ „vrlo malo“ do 5 = „značajno puno“. Anketni upitnik autori su modificirali prema upitniku korištenom u istraživanju Sedlan, König (2012a:255-258), pa je ovo istraživanje ujedno provedeno i kao replikativno.

Prikupljanje podataka potrebnih za istraživanje provedeno je u srpnju i kolovozu 2017. godine korištenjem strukturiranog upitnika među studentima Veleučilišta u Rijeci i to preddiplomski stručni studiji Informatika i Poduzetništvo te specijalistički diplomski studij Poduzetništvo. Anketni upitnik odaslan je na 360 e-mail adresa studenata Veleučilišta u Rijeci te je uz odaziv od 20,6 \% dobiven prigodni uzorak od 73 važeća odgovora studenata. Obuhvaćeni su studenti svih akademskih godina.

\section{REZULTATII RASPRAVA}

Za analizu istraživanjem prikupljenih podataka korišten je alat za statističku analizu „GNU PSPP Statistical Analysis Software" (Release 0.9.0-g3a3d58, verzija 2014.). U analizi su primijenjene metode deskriptivne i inferencijalne statistike te bivarijatne statističke analize (korelacija, ANOVA i linearna regresija).

U sklopu deskriptivne analize analizirano je postoje li među pojedinim kategorijama ispitanika relevantne razlike $u$ odnosu na kontrolne varijable. $U$ tablici 1 prikazani su rezultati za kontrolnu varijablu - vrsta studija te je primjenom t-testa za nezavisne uzorke provjereno postoji li statistički značajna razlika između prosječnih ocjena za istraživane varijable.

Tablica 1. Rezultati deskriptivne statistike i t-testa s obzirom na vrstu studija ispitanika

\begin{tabular}{|c|c|c|c|c|c|c|c|}
\hline \multirow{2}{*}{\multicolumn{2}{|c|}{ Varijabla }} & \multicolumn{2}{|c|}{ Studii informatike } & \multicolumn{2}{|c|}{ Studij poduzetništva } & \multirow{2}{*}{ T-test } & \multirow{2}{*}{ Sig. } \\
\hline & & A.S. & St. dev. & A.S. & St. dev. & & \\
\hline \multicolumn{2}{|c|}{ Sklonost poduzetničkom ponašanju } & 3,20 & 1,55 & 3,85 & 0,98 & $-1,75$ & 0,085 \\
\hline \multicolumn{2}{|c|}{$\begin{array}{l}\text { Vjerojatnost pokretanja vlastitog } \\
\text { posla }\end{array}$} & 2,30 & 1,42 & 3,13 & 1,24 & $-1,90$ & 0,063 \\
\hline \multirow{4}{*}{$\begin{array}{l}\text { Samoprocjena } \\
\text { vlastitih } \\
\text { poduzetničkih } \\
\text { kompetencija } \\
\text { stečenih kroz: }\end{array}$} & $\begin{array}{l}\text { školu/ } \\
\text { fakultet }\end{array}$ & 2,53 & 0,83 & 3,17 & 0,80 & $-2,30$ & $0,025^{*}$ \\
\hline & $\begin{array}{l}\text { osobno } \\
\text { iskustvo }\end{array}$ & 3,88 & 1,03 & 3,86 & 0,74 & 0,04 & 0,965 \\
\hline & natjecanja & 2,91 & 1,33 & 2,76 & 1,02 & 0,39 & 0,699 \\
\hline & udruge & 1,37 & 0,97 & 1,44 & 0,81 & $-0,21$ & 0,838 \\
\hline
\end{tabular}

Napomena: A. S.= aritmetička sredina; Sig. = pouzdanost; ${ }^{*}=$ značajnost razlike na razini $0,05$.

Izvor: istraživanje autora 
Usporedba prosječnih ocjena između ispitanika s različitih studija pokazuje da je riječ o sličnim vrijednostima. Studenti studija poduzetništva ocjenjuju dio promatranih varijabli višim ocjenama u odnosu na studente studija Informatika, osim samoprocjene (percipiranih) vlastitih poduzetničkih kompetencija temeljem osobnog iskustva i natjecanja. Ovakvi rezultati mogu se objasniti činjenicom da su studenti studija Poduzetništvo bliskiji poduzetničkim pojmovima. Ipak, rezultati $\mathrm{t}$-testa pokazuju da su uočene razlike slučajne, tj. nisu statistički značajne $(p>0,05)$, izuzev razlika u samoprocjeni vlastitih poduzetničkih kompetencija ispitanika stečenih kroz školu/fakultet, gdje su razlike statistički značajne ( $t=-2,30 ; p<0,05)$. Može se zaključiti da studenti oba studija imaju sličan stav prema promatranim varijablama. Slične statistički neznačajne razlike utvrđene su i za ostale kontrolne varijable (spol i godina studija), tj. vrlo male razlike u aritmetičkim sredinama.

U tablici 2 prikazani su rezultati za kontrolnu varijablu - poduzetnici u obitelji, koja pripada utjecajima iz okruženja ispitanika te je primjenom t-testa za nezavisne uzorke provjereno postoji li statistički značajna razlika između prosječnih ocjena za istraživane varijable.

Tablica 2. Rezultati deskriptivne statistike i t-testa za ispitanike s različitim okruženjima

\begin{tabular}{|c|c|c|c|c|c|c|c|c|c|}
\hline \multirow{2}{*}{\multicolumn{2}{|c|}{ Varijabla }} & \multicolumn{2}{|c|}{ Svi ispitanici } & \multicolumn{2}{|c|}{$\begin{array}{c}\text { Poduzetnici u } \\
\text { obitelji }(n=23)\end{array}$} & \multicolumn{2}{|c|}{$\begin{array}{c}\text { Bez } \\
\text { poduzetnika u } \\
\text { obitelji }(n=49)\end{array}$} & \multirow[t]{2}{*}{ T-test } & \multirow[t]{2}{*}{ Sig. } \\
\hline & & A.S. & St. dev. & A.S. & St. dev. & A.S. & St. dev. & & \\
\hline \multicolumn{2}{|c|}{$\begin{array}{c}\text { Sklonost poduzetničkom } \\
\text { ponašanju }\end{array}$} & 3,81 & 1,08 & 4,13 & 1,03 & 3,65 & 1,03 & 1,77 & 0,082 \\
\hline \multicolumn{2}{|c|}{$\begin{array}{l}\text { Vjerojatnost pokretanja } \\
\text { vlastitog posla }\end{array}$} & 3,08 & 1,27 & 3,71 & 1,30 & 2,78 & 1,16 & 3,10 & $0,003^{*}$ \\
\hline \multirow{4}{*}{$\begin{array}{l}\text { Samoprocjena } \\
\text { vlastitih } \\
\text { poduzetničkih } \\
\text { kompetencija } \\
\text { stečenih kroz: }\end{array}$} & $\begin{array}{l}\text { školu/ } \\
\text { fakultet }\end{array}$ & 3,07 & 0,83 & 2,95 & 0,89 & 3,13 & 0,80 & $-0,83$ & 0,407 \\
\hline & $\begin{array}{l}\text { osobno } \\
\text { iskustvo }\end{array}$ & 3,90 & 0,77 & 3,91 & 0,90 & 3,90 & 0,71 & 0,05 & 0,958 \\
\hline & natjecanja & 2,79 & 1,05 & 2,58 & 0,87 & 2,88 & 1,11 & $-1,14$ & 0,257 \\
\hline & udruge & 1,41 & 0,79 & 1,33 & 0,70 & 1,44 & 0,83 & $-1,26$ & 0,215 \\
\hline
\end{tabular}

Napomena: A. S.= aritmetička sredina; Sig. = pouzdanost; ${ }^{*}=$ značajnost razlike na razini $0,01$.

Izvor: istraživanje autora

Iz tablice 2 razvidno je da ispitanici ( 32 \% uzorka) u čijoj užoj obitelji postoje poduzetnici iskazuju veću sklonost poduzetničkom ponašanju te izražavaju veću namjeru - vjerojatnost pokretanja vlastitog posla. Pritom su razlike između prosječnih ocjena studenata iz poduzetničkih obitelji i onih bez poduzetnika u užoj obitelji za varijablu vjerojatnosti pokretanja vlastitog posla statistički značajne $(t=3,10 ; p<0,05)$. Nadalje, studenti iz poduzetničkih obitelji niže ocjenjuju školu/fakultet kao izvor poduzetničkih kompetencija od ispitanika koji nemaju poduzetnike u užoj obitelji, no te razlike nisu statistički značajne. 


\section{D. Širola, L. Baltić: Prihvaćenost poduzetničkog načina razmišljanja kod studenata}

Zbornik Veleučilišta u Rijeci, Vol. 6 (2018), No. 1, pp. 197-216

Hipotezom H1 pretpostavlja se da viša razina samoprocjenjenih vlastitih poduzetničkih kompetencija studenata znači veću sklonost poduzetničkom ponašanju. Za testiranje povezanosti vlastitih poduzetničkih kompetencija (uprosječeno i prema četiri načina stjecanja kompetencija) i sklonosti poduzetničkom ponašanju korištena je korelacijska analiza, a rezultati Pearsonova koeficijenta korelacije prikazani su u tablici 3.

Tablica 3. Korelacijska analiza samoprocjene vlastitih poduzetničkih kompetencija i sklonosti poduzetničkom ponašanju

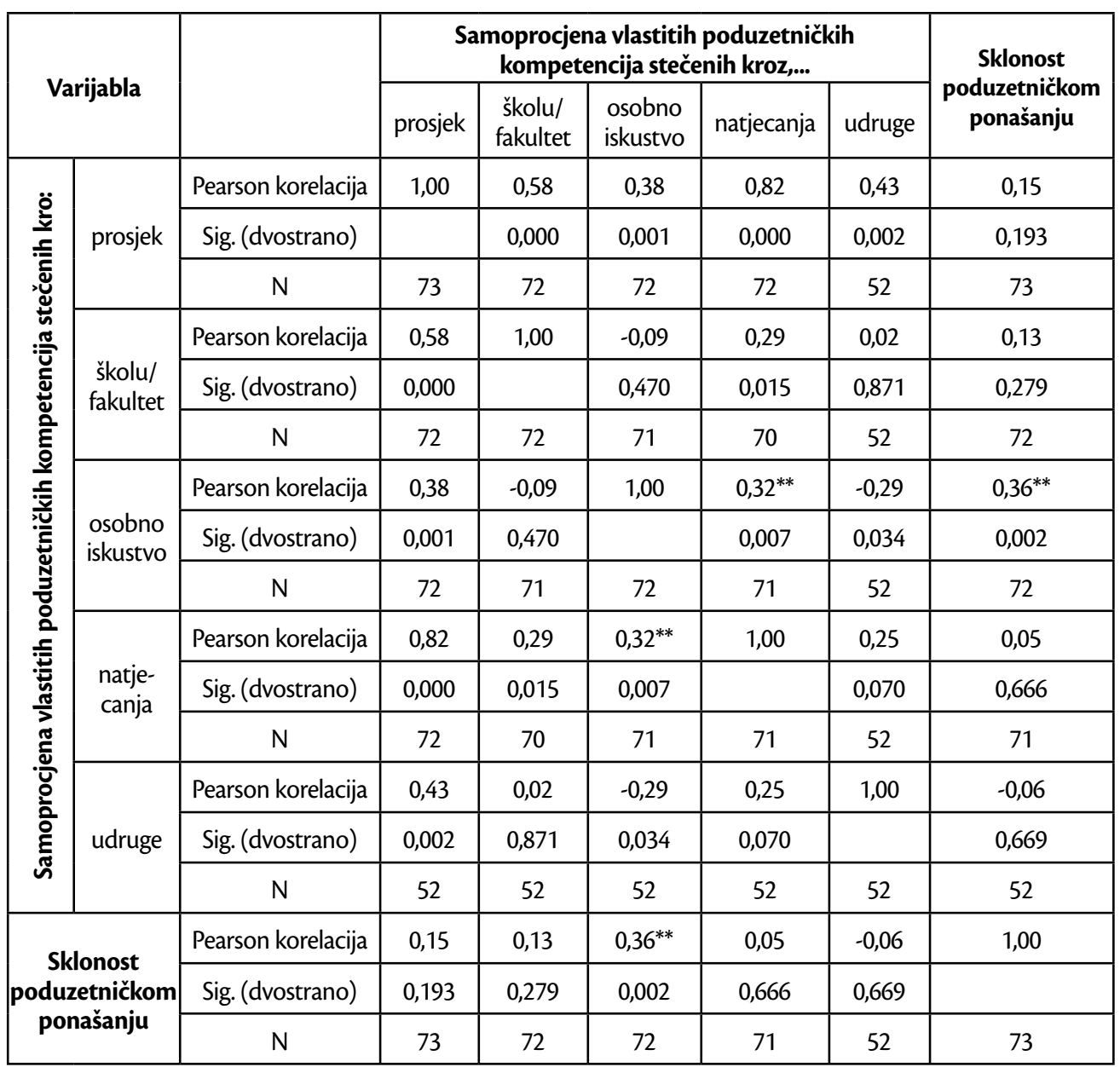

Napomena: ${ }^{* *}$ - korelacija značajna na razini $p=0,01$.

Izvor: istraživanje autora 
Koeficijenti korelacije ukazuju na slabu, pozitivnu i statistički značajnu povezanost između samoprocijenjenih vlastitih poduzetničkih kompetencija ispitanika stečenih kroz osobno iskustvo i sklonosti poduzetničkom ponašanju $(r=0,36 ; p<0,01) .{ }^{4}$ Između uprosječene samoprocjene vlastitih poduzentičkih kompetencija (stečenih kroz sva četiri načina) te kompetencija stečenih kroz školu/fakultet i natjecanja utvrđena je vrlo slaba, pozitivna i statistički neznačajna povezanost sa sklonosti poduzetničkom ponašanju, dok kompetencije stečene kroz rad u udrugama pokazuju vrlo slabu, negativnu i statistički neznačajnu povezanost sa sklonosti poduzetničkom ponašanju. Može se zaključiti da je samoprocijenjena razina vlastitih poduzetničkih kompetencija stečenih kroz osobno iskustvo pozitivno i statistički značajno povezana sa sklonosti poduzetničkom ponašanju te se djelomično prihvaća hipoteza $\mathbf{H 1}$. Ovdje vrijedi istaknuti da korelacijska analiza pokazuje i slabu, pozitivnu i statistički značajnu povezanost između samoprocjene vlastitih poduzetničkih kompetencija stečenih kroz osobno iskustvo i kroz natjecanja te se može zaključiti da studenti koji više procjenjuju vlastite poduzetničke kompetencije stečene sudjelovanjem u natjecanjima ujedno više procjenjuju vlastite poduzetničke kompetencije stečene kroz osobno iskustvo $(r=0,32 ; p<$ $0,01)$ i obratno.

Slijedom hipoteze $\mathrm{H} 2$ potrebno je utvrditi postoji li povezanost varijabli kojima je utvrđivana samoprocijenjena razina vlastitih poduzetničkih kompetencija (stečenih na četiri načina) i varijable vjerojatnosti (namjere) pokretanja vlastitog posla. $U$ tu svrhu provedena je korelacijska analiza tako da je izračunat Pearsonov koeficijent korelacije (tablica 4).

4 Veza je vrlo slaba ako je koeficijent $<0,19$, slaba ako je koeficijent $>0,20<0,39$, srednje jaka ako je koeficijent $>0,40<$ 0,69, jaka ako je koeficijent >0,70<0,89 i vrlo jaka ako je koeficijent >0,90 (Bryan, Cramer, 2005: 219, prema Cohen, Holiday, 1982). 
Tablica 4. Korelacijska analiza samoprocjene vlastitih poduzetničkih kompetencija i vjerojatnosti pokretanja vlastitog posla

\begin{tabular}{|c|c|c|c|c|c|c|c|c|}
\hline \multirow{2}{*}{\multicolumn{2}{|c|}{ Varijabla }} & & \multicolumn{5}{|c|}{$\begin{array}{c}\text { Samoprocjena vlastitih poduzetničkih } \\
\text { kompetencija stečenih kroz: }\end{array}$} & \multirow{2}{*}{$\begin{array}{c}\text { Vjerojatnost } \\
\text { pokretanja } \\
\text { vlastitog } \\
\text { posla }\end{array}$} \\
\hline & & & prosjek & $\begin{array}{l}\text { školu/ } \\
\text { fakultet }\end{array}$ & $\begin{array}{l}\text { osobno } \\
\text { iskustvo }\end{array}$ & natjecanja & udruge & \\
\hline \multirow{15}{*}{ 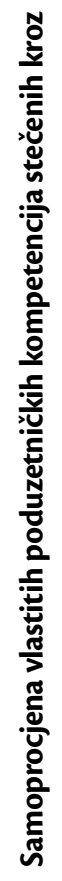 } & \multirow{3}{*}{ prosjek } & Pearsonova korelacija & 1,00 & 0,58 & 0,38 & 0,82 & 0,43 & 0,09 \\
\hline & & Sig. (dvostrano) & & 0,000 & 0,001 & 0,000 & 0,002 & 0,440 \\
\hline & & $\mathrm{N}$ & 73 & 72 & 72 & 72 & 52 & 73 \\
\hline & \multirow{3}{*}{$\begin{array}{c}\text { školu/ } \\
\text { fakultet }\end{array}$} & Pearsonova korelacija & 0,58 & 1,00 & $-0,09$ & 0,29 & 0,02 & 0,00 \\
\hline & & Sig. (dvostrano) & 0,000 & & 0,470 & 0,015 & 0,871 & 0,992 \\
\hline & & $\mathrm{N}$ & 72 & 72 & 71 & 70 & 52 & 72 \\
\hline & \multirow{3}{*}{$\begin{array}{l}\text { Osobno } \\
\text { iskustvo }\end{array}$} & Pearsonova korelacija & 0,38 & $-0,09$ & 1,00 & $0,32^{* *}$ & $-0,29$ & $0,31^{* *}$ \\
\hline & & Sig. (dvostrano) & 0,001 & 0,470 & & 0,007 & 0,034 & 0,009 \\
\hline & & $\mathrm{N}$ & 72 & 71 & 72 & 71 & 52 & 72 \\
\hline & \multirow{3}{*}{ natjecanja } & Pearsonova korelacija & 0,82 & 0,29 & $0,32^{* *}$ & 1,00 & 0,25 & $-0,01$ \\
\hline & & Sig. (dvostrano) & 0,000 & 0,015 & 0,007 & & 0,070 & 0,939 \\
\hline & & $\mathrm{N}$ & 72 & 70 & 71 & 71 & 52 & 71 \\
\hline & \multirow{3}{*}{ udruge } & Pearsonova korelacija & 0,43 & 0,02 & $-0,29$ & 0,25 & 1,00 & $-0,12$ \\
\hline & & Sig. (dvostrano) & 0,002 & 0,871 & 0,034 & 0,070 & & 0,417 \\
\hline & & $\mathrm{N}$ & 52 & 52 & 52 & 52 & 52 & 52 \\
\hline \multirow{3}{*}{\multicolumn{2}{|c|}{$\begin{array}{l}\text { Vjerojatnost } \\
\text { pokretanja } \\
\text { vlastitog posla }\end{array}$}} & Pearsonova korelacija & 0,09 & 0,00 & $0,31^{* *}$ & $-0,01$ & $-0,12$ & 1,00 \\
\hline & & Sig. (dvostrano) & 0,440 & 0,992 & 0,009 & 0,939 & 0,417 & \\
\hline & & $\mathrm{N}$ & 73 & 72 & 72 & 71 & 52 & 73 \\
\hline
\end{tabular}

Napomena: ${ }^{* *}$ - korelacija značajna na razini $p=0,01$.

Izvor: istraživanje autora

Prema koeficijentima korelacije prikazanim u tablici 4 postoji slaba, pozitivna i statistički značajna povezanost između samoprocijenjenih vlastitih poduzetničkih kompetencija ispitanika, stečenih kroz osobno iskustvo i vjerojatnosti pokretanja vlastitog posla $(r=0,31 ; p<0,01) .{ }^{5}$ Slijedi da je samoprocijenjena razina vlastitih poduzetničkih kompetencija stečenih kroz osobno iskustvo pozitivno i statistički značajno povezana s vjerojatnošću pokretanja vlastitog posla te se djelomično prihvaća hipoteza $\mathrm{H} 2$.

5 Veza je vrlo slaba ako je koeficijent $<0,19$, slaba ako je koeficijent $>0,20<0,39$, srednje jaka ako je koeficijent $>0,40<$ 0,69, jaka ako je koeficijent $>0,70<0,89$ i vrlo jaka ako je koeficijent > 0,90 (Bryan, Cramer, 2005: 219, prema Cohen, Holiday, 1982). 
Pored toga treba naglasiti da između uprosječene samoprocjene vlastitih poduzetničkih kompetencija (stečenih kroz sva četiri načina) te kompetencija stečenih kroz školu/fakultet utvrđena je vrlo slaba, pozitivna i statistički neznačajna povezanost s vjerojatnošću pokretanja vlastitog posla, dok kompetencije stečene kroz natjecanja i rad u udrugama pokazuju vrlo slabu, negativnu i statistički neznačajnu povezanost s vjerojatnošću pokretanja vlastitog posla.

Hipotezom H3 želi se utvrditi povezanost sklonosti poduzetničkom ponašanju i vjerojatnosti pokretanja vlastitog posla. Za testiranje ove povezanosti također je korištena korelacijska analiza i pritom je testirana razina i priroda povezanosti sklonosti poduzetničkom ponašanju i vjerojatnosti pokretanja vlastitog posla i to za sve ispitanike te zasebno za one koji imaju poduzetnike u obitelji, budući da su za tu skupinu t-testom utvrđene statistički značajne razlike između prosječnih ocjena (tablica 2). Analiza je provedena izračunavanjem Pearsonova koeficijenta korelacije, a rezultati su prikazani u tablici 5.

Tablica 5. Korelacijska analiza sklonosti poduzetničkom ponašanju i vjerojatnosti pokretanja vlastitog posla

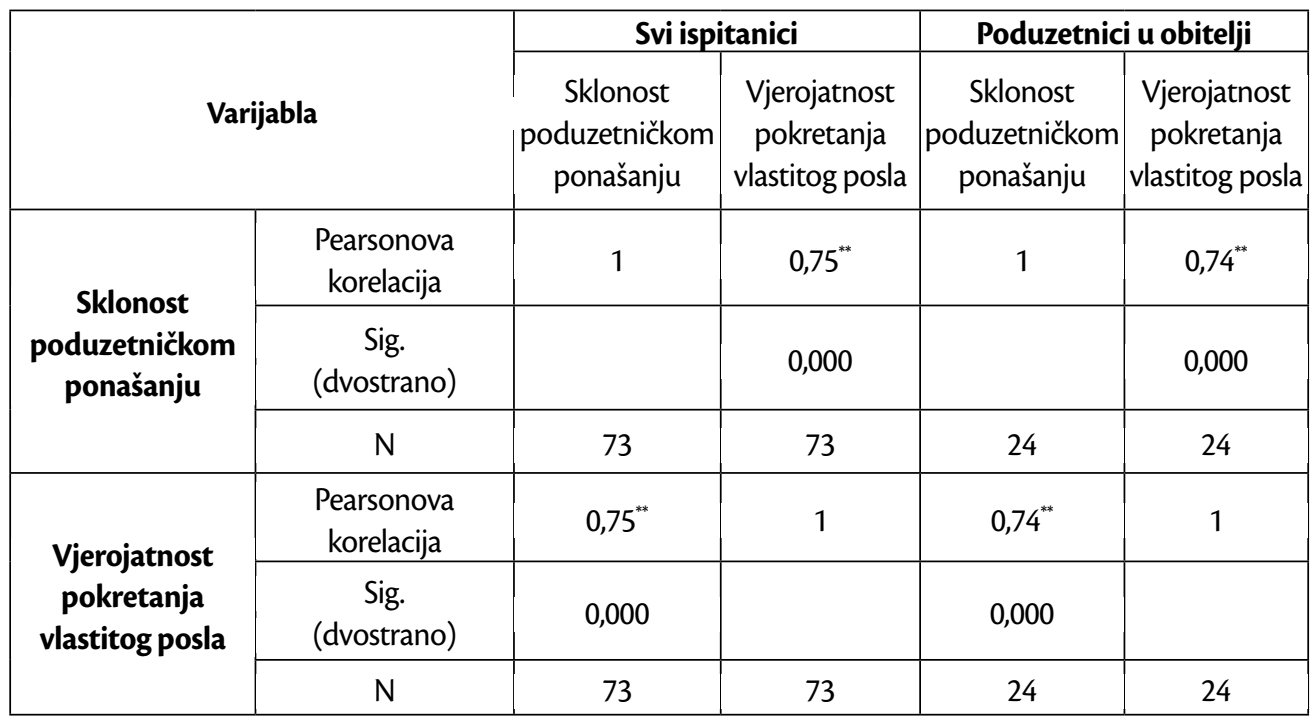

Napomena: ${ }^{* *}$ - korelacija značajna na razini $p=0,01$.

Izvor: istraživanje autora

Koeficijenti korelacije ukazuju na jaku, pozitivnu i statistički značajnu povezanost između sklonosti poduzetničkom ponašanju i vjerojatnosti pokretanja vlastitog posla $(r=0,75 p<0,01)$. Prema tome, što je veća sklonost poduzetničkom ponašanju, to je veća vjerojatnost pokretanja vlastitog posla (i obratno). Gotovo identičnu jaku, pozitivnu i statistički značaju povezanost pokazuju ispitanici koji u užoj obitelji imaju poduzetnike $(r=0,74 p<0,01)$. Ovime se može zaključiti da je stav - sklonost prema poduzetničkom ponašanju pozitivno povezan s vjerojatnošću pokretanja vlastitog posla te se prihvaća hipoteza $\mathbf{H} 3$. 


\section{D. Širola, L. Baltić: Prihvaćenost poduzetničkog načina razmišljanja kod studenata Zbornik Veleučilišta u Rijeci, Vol. 6 (2018), No. 1, pp. 197-216}

Da bi se utvrdila pozitivna linearna veza između sklonosti poduzetničkom ponašanju i vjerojatnosti pokretanja vlastitog posla, predvidjela razina vjerojatnosti pokretanja vlastitog posla i utvrdila razina i značajnost utjecaja sklonosti poduzetničkom ponašanju (kao nezavisne varijable) na vjerojatnost pokretanja vlastitog posla (kao zavisne varijable), provedena je linearna regresijska analiza. Analiza je provedena na uzorku od 73 (važeća odgovora) ispitanika, što zadovoljava kriterij najmanjeg predloženog odnosa broja elemenata u uzorku i broja nezavisnih varijabli (5: 1). U konkretnom slučaju, odnos je $73: 1$ (73 ispitanika i 1 varijabla). Radi provjere preduvjeta reprezentativnosti rezultata regresijske analize provedena je analiza normalnosti distribucije. $U$ tablici 6 prikazani su koeficijenti asimetrije i koeficijenti zaobljenosti varijabli u regresijskom modelu.

Tablica 6. Provjera normalnosti distribucije varijabli u regresijskom modelu

\begin{tabular}{|c|c|c|c|c|}
\hline Varijable & A.S. & St. dev. & Asimetrija & Zaobljenost \\
\hline $\begin{array}{c}\text { Sklonost poduzetničkom } \\
\text { ponašanju }\end{array}$ & 3,81 & 1,09 & $-0,60$ & $-0,38$ \\
\hline $\begin{array}{c}\text { Vjerojatnost pokretanja } \\
\text { vlastitog posla }\end{array}$ & 3,08 & 1,28 & 0,01 & $-0,99$ \\
\hline
\end{tabular}

Izvor: istraživanje autora

Uočava se blaga negativna asimetrija kod varijable sklonost poduzetničkom ponašanju, dok varijabla vjerojatnost pokretanja vlastitog posla ima blagu pozitivnu asimetriju. Svi koeficijenti asimetrije su unutar granica prihvatljivosti za normalnu distribuciju. ${ }^{6}$ Vrijednosti koeficijenata, kao i uvid u grafički prikaz, ukazuje da je varijabla vjerojatnost pokretanja vlastitog posla asimetrična na desno (eng. right skewed distribution). Smatra se, međutim, da je regresijska analiza relativno robusna te se može koristiti iako nije zadovoljena pretpostavka o normalnosti podataka (Hair et al., 2010: 208). Koeficijenti korelacije u regresijskom modelu prikazani su u tablici 7.

Tablica 7. Koeficijenti korelacije u regresijskom modelu (sažetak modela)

\begin{tabular}{|c|c|c|c|}
\hline $\mathbf{R}$ & $\mathbf{R}^{\mathbf{2}}$ & Prilagođeni $\mathbf{R}^{\mathbf{2}}$ & $\begin{array}{c}\text { Standardna pogreška } \\
\text { procjene }\end{array}$ \\
\hline 0,75 & 0,56 & 0,56 & 0,85 \\
\hline
\end{tabular}

Izvor: istraživanje autora

Koeficijent multiple korelacije R, uz istovremenu prisutnost svih nezavisnih varijabli (prediktora), iznosi 0,75, pa se može zaključiti da postoji vrlo visoka (jaka) povezanost između sklonosti poduzetničkom ponašanju i vjerojatnosti pokretanja vlastitog posla.' Prema koeficijentu determinacije $\left(R^{2}=0,56\right)$ varijable u modelu dijele $56 \%$ zajedničkih faktora. To znači da se $56 \%$ varijance (informacija)

6 Preporučene vrijednosti koeficijenta asimetrije su između $+1.0 \mathrm{i}-1.0$, što označava granice normalnosti distribucije podataka (Leech et al., 2005: 21).

7 Koeficijenti multiple korelacije $(R)$ interpretiraju se slično kao i koeficijenti korelacije $(r)$, tj. niska razina povezanosti $(R)^{3} 0,14<0,36\left(r={ }^{3} 0,1<0,3\right)$; srednja razina $(R)^{3} 0,36<0,51\left(r={ }^{3} 0,3<0,5\right)$ visoka razina $(R)^{3} 0,51<0,70+\left(r={ }^{3} 0,5\right.$ $<0,7)$ i vrlo visoka $(R)^{3} 0,7\left(r={ }^{3} 0,7\right)$ prema Leech et al., 2005: 56 . 
vjerojatnosti pokretanja vlastitog posla može predvidjeti (objasniti) varijablom sklonosti poduzetničkom ponašanju.

Tablica 8. Analiza varijance (ANOVA) za regresijski model

\begin{tabular}{|c|c|c|c|c|c|}
\hline & Zbroj kvadrata & Stupnjevi slobode & Kvadrat prosjeka & F & Sig. \\
\hline Regresija & 66,20 & 2 & 66,20 & 91,60 & 0,000 \\
Ostatak & 51,31 & 71 & 0,72 & & \\
Ukupno & 117,51 & 72 & & & \\
\hline
\end{tabular}

Izvor: istraživanje autora

Analizom varijance (tablica 8), utvrđeno je da su rezultati statistički značajni, $F(2,71)=91,60$, $p<0,01$. To znači da ova nezavisna varijabla značajno predviđa zavisnu varijablu, tj. da sklonost poduzetničkom ponašanju uspješno objašnjava vjerojatnost pokretanja vlastitog posla. Regresijske koeficijente i njihovu značajnost u regresijskom modelu te pokazatelje kolinearnosti sadrži tablica 9.

Tablica 9. Regresijski koeficijenti i pokazatelji kolinearnosti u regresijskom modelu

\begin{tabular}{|c|c|c|c|c|c|}
\hline & \multicolumn{2}{|c|}{$\begin{array}{c}\text { Nestandardizirani } \\
\text { koeficijent }\end{array}$} & $\begin{array}{c}\text { Standardizirani } \\
\text { koeficijent }\end{array}$ & \multirow{2}{*}{$\mathrm{t}$} & \multirow{2}{*}{ Sig. } \\
\cline { 2 - 4 } & $\mathrm{B}$ & $\begin{array}{c}\text { Standardna } \\
\text { pogreška }\end{array}$ & Beta & & \\
\hline (Konstanta) & $-0,27$ & 0,36 & 0,00 & $-0,75$ & 0,457 \\
Sklonost poduzetničkom ponašanju & 0,88 & 0,09 & 0,75 & 9,57 & 0,000 \\
\hline
\end{tabular}

Izvor: istraživanje autora

Prema dobivenim rezultatima u tablici 9 (B koeficijenti) povećanje rezultata na ljestvici sklonosti poduzetničkom ponašanju za jedan bod povezano je s prosječnim povećanjem rezultata na ljestvici vjerojatnosti pokretanja vlastitog posla za 0,88 bodova. Pritom je vrijednost standardne pogreške regresijskog koeficijenta mala, što ukazuje na pouzdaniju procjenu i uže intervale pouzdanosti regresijskog koeficijenta, kada bi se računao za različite uzorke iz iste populacije (Hair et al. 2010: 212). Nadalje, iz tablice 9 razvidno je da se u promatranom modelu vrijednost t-testa značajno razlikuje od nule te je signifikantna $(p<0,01)$, što znači da nezavisna varijabla, sklonost poduzetničkom ponašanju, značajno pridonosi vjerojatnosti pokretanja vlastitog posla (Hair et al. 2010: 212). Rezultati analize dodatno potvrđuju hipotezu H3, odnosno ukuzuju kojim intenzitetom iskazana sklonost poduzetničkom ponašanju izravno, pozitivno i statistički značajno utječe na vjerojatnost pokretanja vlastitog posla.

\section{RASPRAVA I ZAKLJUČAK}

Svrha ovog rada bila je analizirati čimbenike koji utječu na razinu prihvaćenosti poduzetničkog načina razmišljanja kod studenata. $U$ tom kontekstu iznimno je važna uloga tercijarnog 
poduzetničkog obrazovanja. Kako je u ovom radu djelomično replicirano istraživanje provedeno od strane Sedlan König (2012a), uspoređeni su ključni rezultati dostupni u oba istraživanja.

Tablica 10. Analiza usporedivih rezultata istraživanja

\begin{tabular}{|c|c|c|c|c|}
\hline \multirow{2}{*}{ Varijable } & \multicolumn{2}{|c|}{$\begin{array}{c}\text { Istraživanje 2017. g.; uzorak 73 } \\
\text { studenta (Veleučilište Rijeka) }\end{array}$} & \multicolumn{2}{c|}{$\begin{array}{c}\text { Istraživanje 2012. g.; uzorak } \\
324 \text { studenta (EFOS Osijek) }\end{array}$} \\
\cline { 2 - 5 } & A.S. & St. dev. & A.S. & St. dev. \\
\hline $\begin{array}{c}\text { Sklonost poduzetničkom } \\
\text { ponašanju - svi ispitanici }\end{array}$ & 3,81 & 1,09 & 3,77 & 1,12 \\
\hline $\begin{array}{c}\text { Sklonost poduzetničkom } \\
\text { ponašanju - obitelji poduzetnika }\end{array}$ & 4,13 & 1,03 & 4,23 & 0,97 \\
\hline $\begin{array}{c}\text { Vjerojatnost pokretanja vlastitog } \\
\text { posla - svi ispitanici }\end{array}$ & 3,08 & 1,28 & 3,19 & 1,08 \\
\hline $\begin{array}{c}\text { Vjerojatnost pokretanja vlastitog } \\
\text { posla - obitelji poduzetnika }\end{array}$ & 3,71 & 1,30 & 3,64 & 1,11 \\
\hline
\end{tabular}

Napomena: A. S.= aritmetička sredina;

Izvori: Sedlan König (2012a: 202, 206-207, 215); istraživanje autora

Predstavljena analiza pokazuje da su razlike između dvaju uzorka u pogledu sklonosti poduzetničkom ponašanju i vjerojatnosti pokretanja vlastitog posla vrlo male. Ujedno je potvrđeno da je okruženje (poduzetnici u obitelji) vrlo značajan čimbenik. Pored toga i rezultati samoprocjene vlastitih poduzetničkih kompetencija u oba istraživanja pokazuju statistički značajne rezultate korelacije za osobno iskustvo ( $u$ istraživanju iz 2012. godine i za natjecanja), dok poduzetničko obrazovanje (škola/fakultet), ne predstavlja statistički važan čimbenik stjecanja poduzetničkih kompetencija.

Time su ovim, djelomično replikativnim istraživanjem potvrđeni zaključci prethodnog istraživanja i ustanovljeno da, usprkos petogodišnjem odmaku, nije došlo do povećanja značaja koji na jačanje sklonosti poduzetničkom ponašanju i vjerojatnost pokretanja posla ima formalno visokoškolsko obrazovanje. Ograničenje u široj primjenjivosti dobivenih rezultata istraživanja u ovom radu predstavlja relativno mali uzorak, dobiven unutar jedne visokoškolske hrvatske ustanove.

Nadalje, rezultati su usporedivi sa sličnim istraživanjima utjecaja poduzetničkog obrazovanja izvan Republike Hrvatske, koja se pretežito zaustavljaju na teorijskim zaključcima, a dijelom i propuštaju uzeti u obzir sve potencijalne prediktore i moderatore utjecaja poduzetničkog obrazovanja na stavove, namjere ili uspješnost stjecanja poduzetničkih kompetencija (primjerice: Liñán i Fayolle, 2015: 919, Rideout i Gray, 2013: 345). Naime, usprkos dokazivanju postavljenih hipoteza kojima se pretpostavlja utjecaj poduzetničkog obrazovanja na promjene, primjerice, stavova, uvjerenja ili namjera ispitanika, vrlo su rijetka objektivna mjerenja koja bi dokazane promjene u poduzetničkom 
ponašanju testirala i kroz pokazatelje, poput broja samozaposlenih osoba ili novo osnovanih poduzeća.

Ipak zaključci ovog istraživanja na tragu su onih (primjerice Krueger, 2015: 6) koja upućuju na nedostatke postojećih poduzetničkih obrazovnih programa u pogledu utjecaja na jačanje poduzetničkog načina razmišljanja te se prepoznaje potreba promjene u načinu poučavanja poduzetništva, sa učenja 'o' poduzetništvu, na učenje kako praktično 'činiti' poduzetništvo. Slijedi da su nužne korekcije pristupa poduzetničkom obrazovanju koje treba obuhvatiti inoviranje poduzetničkih obrazovnih programa, odnosno ishoda učenja (sukladno Poduzetničkom okviru kompetencija, Bacigalupo et al., 2016: 17), kao i metoda poučavanja, primjerice, primjenom metoda aktivnog učenja, koje olakšavaju stjecanje vještina i znanja u području poduzetništva, odnosno poduzetničkog ponašanja (Brkanlić et al., 2012: 172).

Pritom je svakako poželjno uzeti u obzir model (shema 1), koji je polazište ovog istraživanja i ujedno objašnjava zašto programi u poduzetničkom obrazovanju koji se temelje na usvajanju znanja i psihološkim značajkama poduzetnika ne donose očekivane ishode. Naime, uz iste ili slične osobine i znanja pojedinci ne pokazuju podjednako poduzetničko ponašanje zbog različitog stupnja razvijenosti određene kategorije poduzetničke kompetencije, a posljedično i različito razvijenih poduzetničkih stavova i namjera (Sedlan König, 2012a: 148).

\section{LITERATURA}

Ajzen, I. (1991) The Theory of Planned Behavior, Organizational behavior and human decision processes, Vol 50, p. 179211

Bacigalupo, M., Kampylis, P., Punie, Y., Van den Brande, G. (2016) EntreComp: The Entrepreneurship Competence Framework, Luxembourg: Publication Office of the European Union

Bandura, A. (1994) Self-efficacy u V. S. Ramachaudran (Ed.), Encyclopedia of human behavior (Vol. 4, p. 71-81); New York: Academic Press. (Reprinted in H. Friedman [Ed.], Encyclopedia of mental health. San Diego: Academic Press, 1998).

Bandura, A. (2001) Social Cognitive Theory: An Agentic Perspective, Annual Review of Psychology, Vol 52, No:1, p. 1-26

Baltić, L. (2017) Prihvaćenost poduzetničkog načina razmišljanja kod studenata, završni rad, Rijeka: Veleučilište u Rijeci

Bird, B. (1995) Toward a theory of entrepreneurial competency, Advances in Entrepreneurship, Firm Emergence, And Growth, Volume 2, p. 51-72

Bird, B. (1988) Implementing Entrepreneurial Ideas: The Case for Intention, Academy of Management Review, Vol 13, No 3, p. $442-453$

Brkanlić, S., Radakov, S., Vapa, B. (2012) Metode aktivnog učenja u sistemu visokog obrazovanja, Učenje za poduzetništvo, Vol. 2, No 1, p. 171-176

Bryman, A., Cramer, D. (2005) Quantitative Data Analysis with SPSS 12 and 13: A Guide for Social Scientists, London, New York: Routledge

European Commision (2013) Entrepreneurship 2020 Action Plan, Brussels, http://eur-lex.europa.eu/LexUriServ/ LexUriServ.do?uri=COM:2012:0795:FIN:en:PDF, 25. 12. 2013.

European Commision, DG Enterprise and Industry (2012) Effects and impact of entrepreneurship programmes in higher education, https://ec.europa.eu/growth/content/effects-and-impact-entrepreneurship-programmes-highereducation, 7. 11. 2015. 


\section{D. Širola, L. Baltić: Prihvaćenost poduzetničkog načina razmišljanja kod studenata Zbornik Veleučilišta u Rijeci, Vol. 6 (2018), No. 1, pp. 197-216}

European Commission (2008) Explaining the European QualificationsFramework for Lifelong Learning. https://ec.europa. eu/ploteus/documentation\#documentation_74, 17. 10.2017.

European Commission (2003) Green Paper Entrepreneurship in Europe, Brussels, http://eur-lex.europa.eu/LexUriServ/ site/en/com/2003/com2003_0027en01.pdf, 4. 1. 2008.

Hair, J. F., Black, W. C., Babin, B. J., Anderson, R. E. (2010) Multivariate Data Analysis: A Global Perspective, $7^{\text {th }}$ Edition, New Yersey, Upper Saddle River: Pearson Education Inc.

Hisrich, R. D., Peters, M. P., Shepherd, D. A. (2011) Poduzetništvo, Zagreb: Mate d. o. o.

lakovleva, T. i Kolvereid, L. (2009) An integrated model of entrepreneurial intentions, International Journal of Business and Globalisation, Vol. 3, No. 1, p. 66-80

Kautonen, T., Van Gelderen, M., Tornikoski, E. T. (2011) Predicting entrepreneurial behaviour: a test of the theory of planned behaviour, Applied Economics, Taylor \& Francis (Routledge), 45, (06), p. 697-707

Krueger, N. (2015) Entrepreneurial Education in Practice, Part 1 - The Entrepreneurial Mindset, Entrepreneurship360, Thematic Paper, OECD (LEED Programme) i European Commission (DG Education and Culture)

Krueger, N. F. Jr.; Reilly, M. D.; Carsurd, A. L. (2000) Competing models of Entrepreneurial Intentions, Journal of Business Venturing no. 5/6, p. 411-432.

Kuratko, D. F. (2004) Entrepreneurship education in the 21st century: From legitimization to leadership, A Coleman Foundation White Paper USASBE National Conference January 16, https://pdfs.semanticscholar.org/d89d/3a2a96 b5c645ab42b0e28f6d73be7f961fe6.pdf, 16. 7. 2016.

Kuratko, D. F. (2003) Entrepreneurship education: Emerging trends and challenges for the 21st century, Coleman Foundation White Paper Series for the U.S. Association of Small Business \& Entrepreneurship, http://citeseerx.ist.psu.edu/ viewdoc/download?doi=10.1.1.511.1631\&rep=rep1\&type=pdf, 4. 3. 2016.

Leech, N. L., Barett, K. C., Morgan, G. A. (2005) SPSS for Intermediate Statistics: Use and Interpretation, $2^{\text {nd }}$ Edition, New Jersey: Lawrence Erlbaum Associates Publishers

Liñán, F. i Fayolle, A. (2015) A systematic literature review on entrepreneurial intentions: citation, thematic analyses, and research agenda, International Entrepreneurship and Management Journal, Volume 11, Issue 4, p. 907-933

Martin, B., McNally, J. J., Kay, M. (2013) Examining the Formation of Human Capital in Entrepreneurship: A Meta-Analysis of Entrepreneurship Education Outcomes, Journal of Business Venturing, 28 (2): p. 211-224

McGee, J. E., Peterson, M., Mueller, S. L., Sequeira, J. M. (2009) Entrepreneurial Self-Efficacy: Refining the Measure, Entrepreneurship Theory and Practice, Volume 33, Issue 4, p. 965-988

Ministarstvo poduzetništva i obrta (2013) Strategija razvoja poduzetništva 2013. - 2020., Zagreb, http://www.minpo.hr, 2. 1.2014.

Mitchelmore, S i Rowley, J. (2010) Entrepreneurial competencies: a literature review and development agenda, International Journal of Entrepreneurial Behaviour\& Research, Vol. 16 No. 2, p. 92-111

Rideout, E. C. i Gray, D. O. (2013) Does Entrepreneurship Education Really Work A Review and Methodological Critique of the Empirical Literature on the Effects of University-Based Entrepreneurship Education, Journal of Small Business Management, Vol 51, No 3, p. 329-351

Sedlan König, Lj. (2013) Entrepreneurial competence as an outcome of higher education, 3rd International Scientific Conference Economy in Integration "Using Knowledge to Move from Recession to Prosperity", Umihanić, B., Kurtić, A., Kokorović J., Nuhanović, A. (ur.), Ekonomski fakultet Tuzla, p. 803-820

Sedlan König, Lj. (2012a) Metodologija visokoškolskog obrazovanja u funkciji poticanja poduzetničkog ponašanja, doktorska disertacija, Sveučilište Josipa Jurja Strossmayera u Osijeku, Ekonomski fakultet u Osijeku

Sedlan König, Lj. (2012b) Razvijanje poduzetničkog ponašanja u cilju povećanja zapošljivosti studenata ekonomskih fakulteta, Ekonomsko obrazovanje u Republici Hrvatskoj - jučer, danas, sutra : zbornik radova znanstvene konferencije, Zagreb, (ur. Čavrak, V., Gelo, T.), p. 479-496.

Širola, D. (2014) Poduzetništvo, Rijeka: Veleučilište u Rijeci 


\title{
ENTREPRENEURIAL MINDSET ADOPTION AMONG STUDENTS 3
}

\begin{abstract}
In order to enhance comprehensive utilization and development of personal and social potential, the European Union considers, promotes and fosters the entreprenurial mindset, as one of the most important factors, which can strenghten the competitive power of economy, as well as the role of supporting institutions, especially educational. The purpose of this research encompasses identifying the factors which enhance the propensity for entrepreneurial behaviour and the probability of the new venture creation. Although policymakers have considerable expectations about the role of higher entrepreneurial education in the process of further widening of the entreprenurial mindset, according to the results of this study, entrepreneurial education in the Republic of Croatia is considered as an insignificant factor in stimulating entreprenurial behaviour and as a source of entrepreneurial competence. Consequently, the research results (a study was conducted among students at the Polytechnic of Rijeka) pointed out that students in Croatia can rely mostly on their own experience and entrepreneurial family background, as the main significant factors, which have a positive impact on enhancing their propensity for entrepreneurial behaviour and the probability of new venture creation. Furthermore, the results show that the propensity for entrepreneurial behaviour represents a significant predictor of the level of probability of new venture creation. These results imply that policymakers and others responsible for tertiary entrepreneurship education should consider implementing changes in learning outcomes, as well as in teaching methods, in order to fulfil its mission in strengthening the entrepreneurial mindset and entrepreneurial behaviour.
\end{abstract}

Key words: entrepreneurial behaviour, entrepreneurial competencies, entrepreneurship education

PhD., Senior Lecturer, Polytechnic of Rijeka, Vukovarska 58, 51000 Rijeka, Croatia. E-mail: davor.sirola@veleri.hr

2 BA in Entrepreneurship, Student, Polytechnic of Rijeka, Vukovarska 58, 51000 Rijeka, Croatia. E-mail: Ibaltic@veleri.hr

3 Received: 15 January 2018; Accepted: 1 March 2018 
